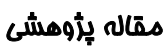

\section{اثرات متفورمين بر ميزان خربيهاى خون در رتهاى باردار هيبر كليسميك و نوزادان}

زيبا رجائى '، موسى الرضا حاج زاده '، آزاده نظرى '، مقدسه شمس'

' استاديار تروه فيزيولوزى، دانشگاه علوم يزشكى مشهد، مشهد، ايران

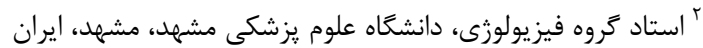

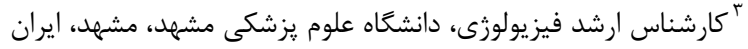

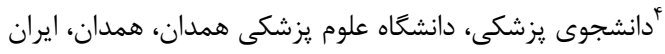

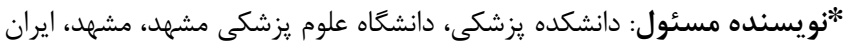

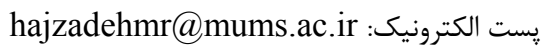

وصول: وسا

زمينه و هدف: ديابت حاملتى نوعى عدم تحمل به تلوكز، به هر ميزان مى باشد كه شروع و يا تشخيص اوليه آن در دوره باردارى است.

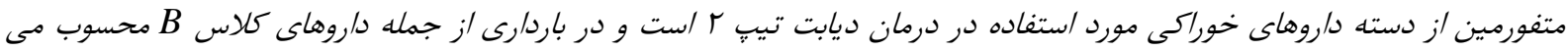

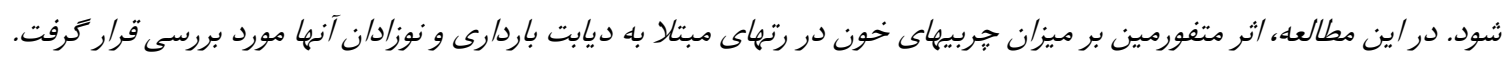

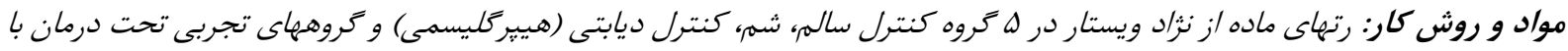

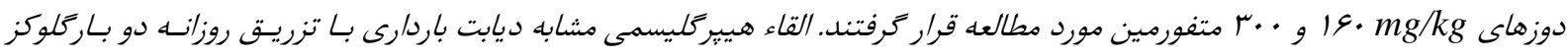
هيبرتونيك با دوز

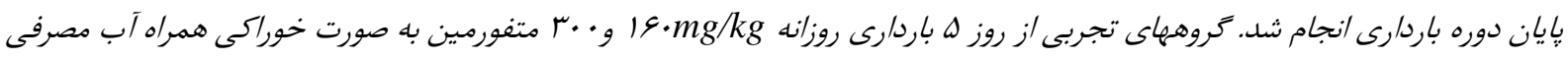

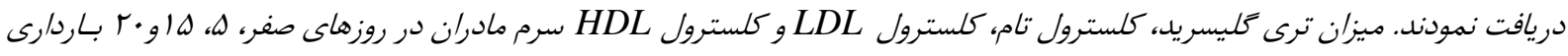

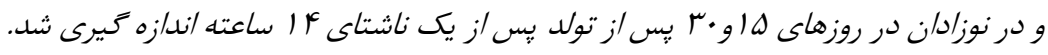

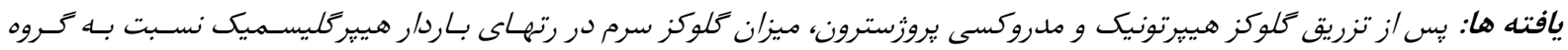

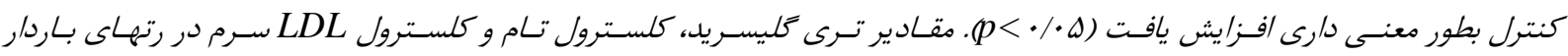

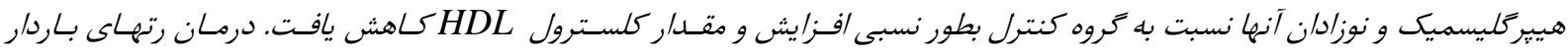

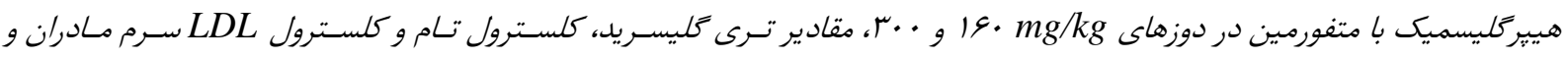
نوزاد/ن را نسبت به كروه كنترل به طور نسبى كاهش و ميزان كلسترول HDL را افزايش داد كه البته /ين تغييرات معنى دار نبود.

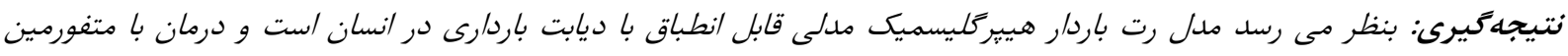

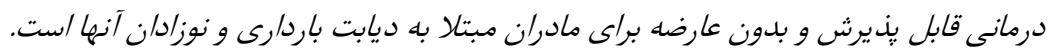

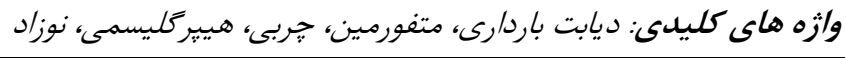
مقدمه

جفتى، فاكتورهاى مقاومت به انسولين ايجاد مى كنند كه در سه ماهه آخر بيشتر مشهود مى باشد. ارزيابى خطر ديابت در اولين مراجعه مادر باردار به يزشك ييشنهاد مى خـى

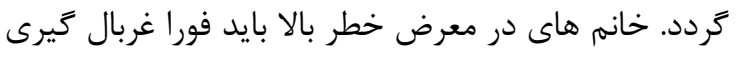

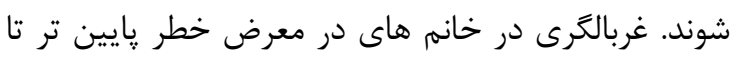

ديابت ناشى از باردارى' (GDM)، با هرگونه اختلال در

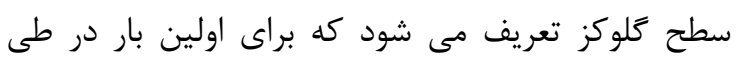

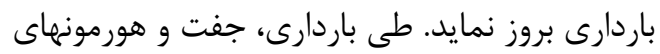

1. Gestational Diabetes Mellitus 
غلظت آن در خون بند ناف در حدود • ه. غلظت مادىى است [ب 1 []. لذا لازم است مطالعات بيشترى بويزه مطالعات حيوانى در مورد اثرات مصرف متفورمين در دوران باردارى بر سلامت مادر و جنين صورت كيرد تا زوايا و ابعاد بيشترى از اثرات آن شناخته شود. در اين راستا، هدف از انجام اين مطالعه تجربى، بررسى اثر متفورمين بر ميزان جربيهاى خون رتهاى باردار هيير كليسميك و نوزادان آنها تا يك ماه يِ از تولد است. شايد درمان با متفورمين كه

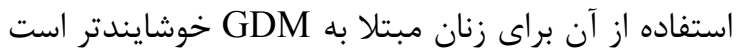

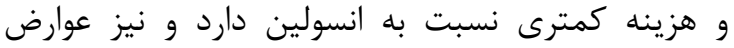

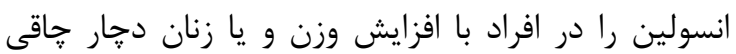

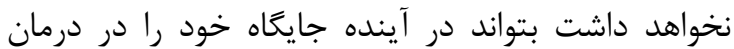
ديابت باردارى در زنان باردار بدست آورد. روش كار

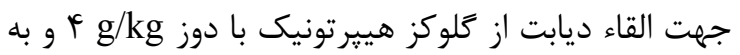
دنبال آن تزريق مدروكسى يروزسترون (كه به علت اثرات

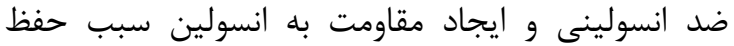
هييركليسمى براى مدت طولانى ترى مى كردد) با دوز

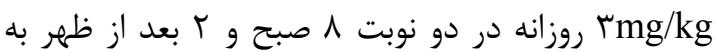

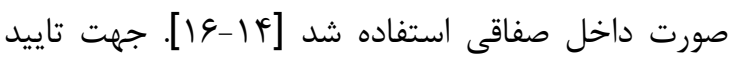

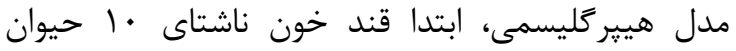

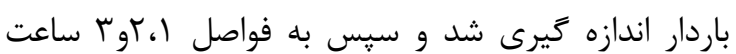
بعد از تزريق كلوكز هييرتونيك و مدروكسى يروزسترون، انداره ميزان قند خون حيوانات با كرفتن يك قطره خون از دم دمريق

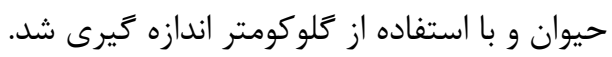
حيوانات مورد استفاده در اين مطالعه تجربى، رتهاى مادئ كاده

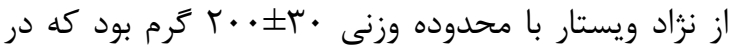

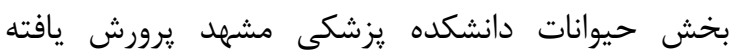

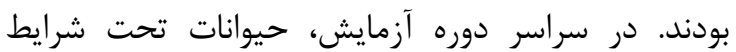

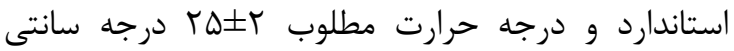

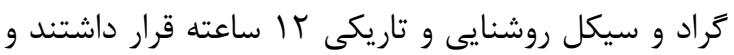
دسترسى آنها به آب و غذا به طور آزاد بود. سيس حئ حيوانات

بصورت تصادفى به له گروه زير دسته بندى شدند:

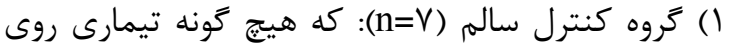

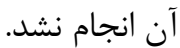

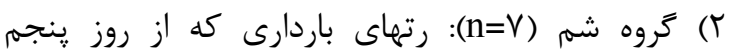

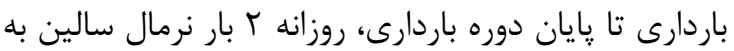

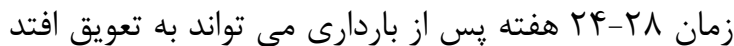

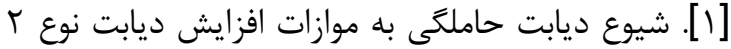
رو به افزايش است و زنانى كه در معرض خطر ابتلا به

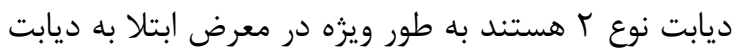
حاملتى قرار دارند [ז]. در كشور ما نيز در سالهاى اخير

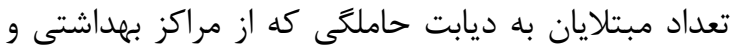

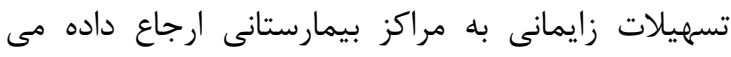

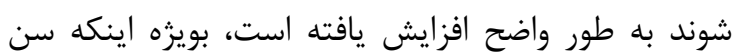

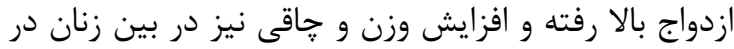

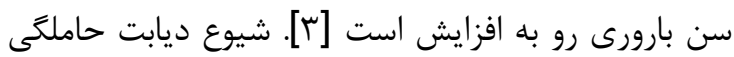

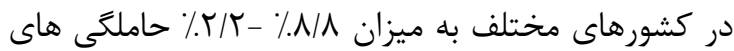
سالانه كزارش شده است [F] ريسك فاكتورهاى ايجاد ديابت باردارى شامل مواردى

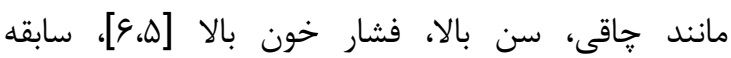
خانوادگى، بارورى نامتوازن قبلى، نزاد، سندرم تخمدان

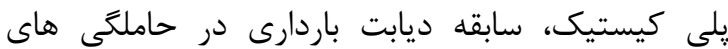

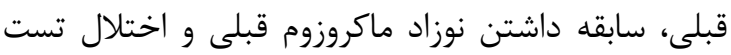

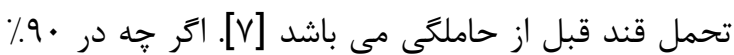

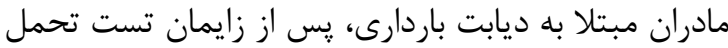

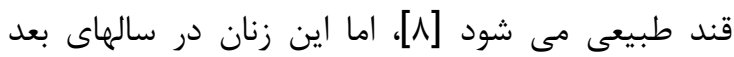

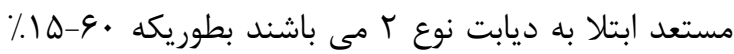
زنان با GDM به فاصله ها-ه سال يُ إز زايمان دجار

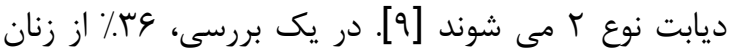

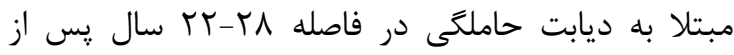

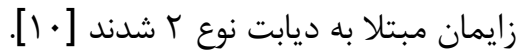
در سالهاى اخير مطالعاتى در زمينه ديابت دوران باردارى

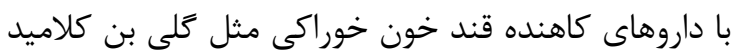

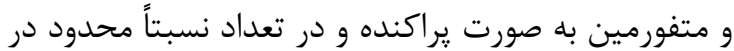
مطالعات آينده نكر انجام شده است كه در كوتاه مدت

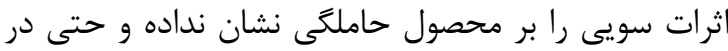
مواردى مزيت هايى نيز داشته است. متفورمين كارآمدى دارى بسيار خوبى در كاهش مقاومت به انسولين (افزايش دايش حساسيت بافتى به انسولين) به ويزه در موارد مقاومت به به بهاريه

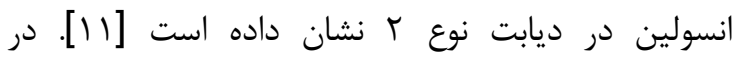
يروهش هاى سالهاى اخير نيز موارد اميدواركننده اى از اثرات متفورمين در موارد ديابت باردارى كزارش شده است داست

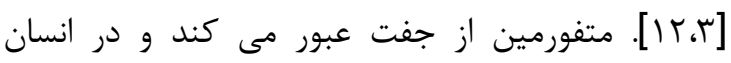


همانطور كه نمودار ا نشان مى دهد غلظت ترى گليسـريد

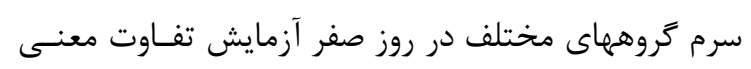

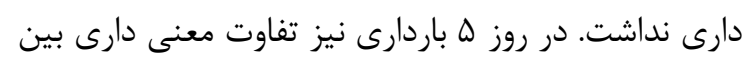

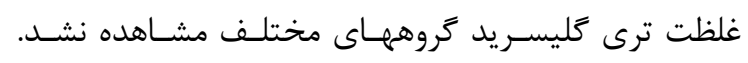

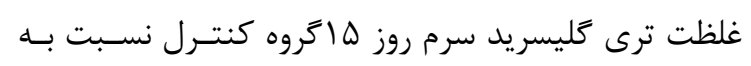

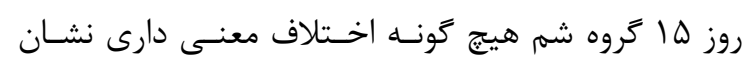

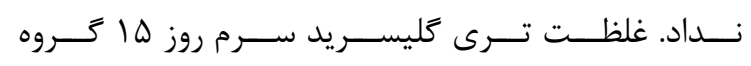
هيير Fليسميك نسبت به روز ها گرووه كنتــرل بـه ميـزان

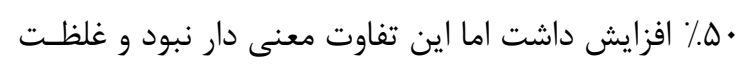
ترى گليسريد سرم در زروههاى تجربى اوץ در مقايسه بـا

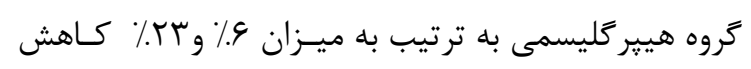

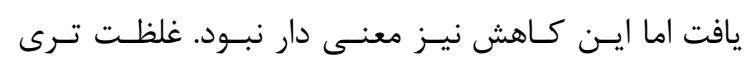

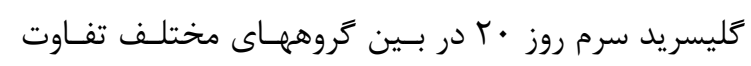
معنى دارى نداشت.

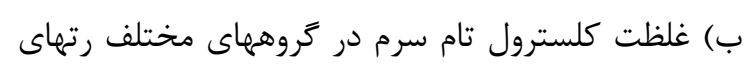

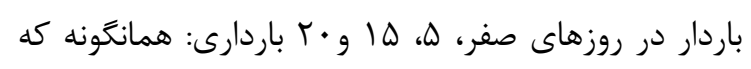

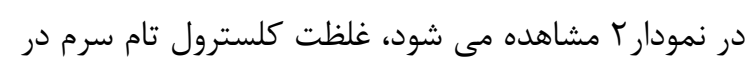

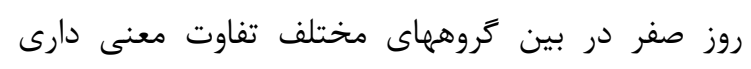

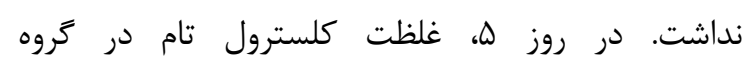

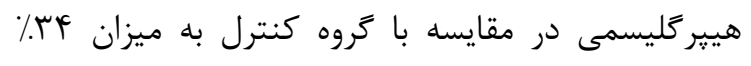

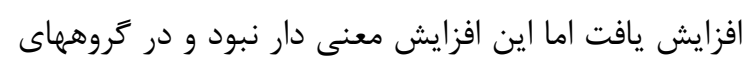

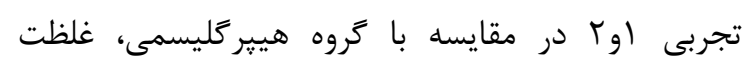
كلسترول تام بطور جزئى كاهش يافت اما اين كاهش نيز

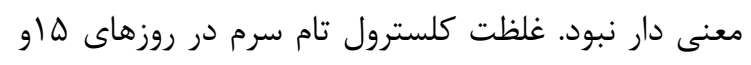
• r در بين گروه هاى مختلف تفاوت معنى دارى نداشت.

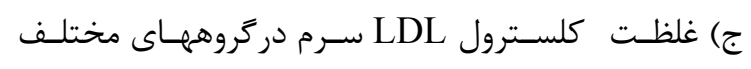

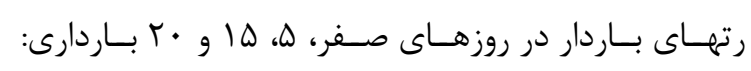

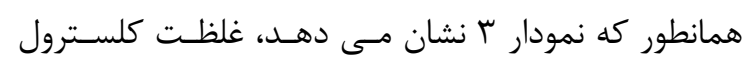

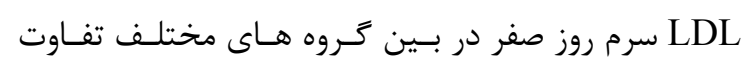

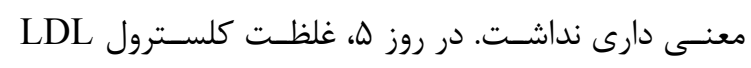

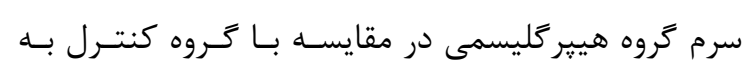

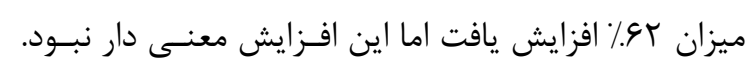

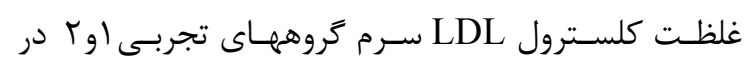

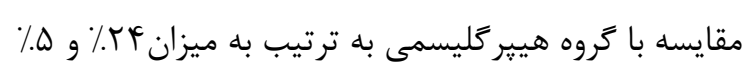
كاهش يافت كه اين كاهش نيز معنى دار نبود. در روز ها ها

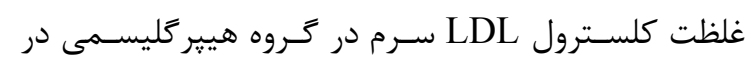

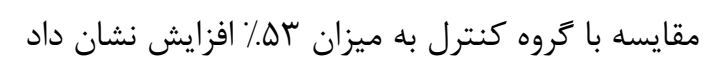

صورت داخل صفاقى با حجمهاى مساوى با كلوكز هييرتونيك و مدروكسى يروزسترون دريافت نمودند.

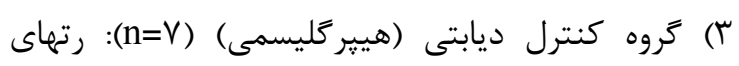

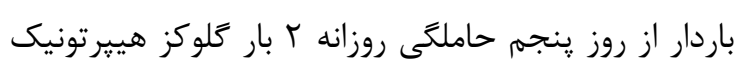
و مدروكسى يروزسترون به صورت داخل صفاقى تا يايان دوره باردارى دريافت نمودند.

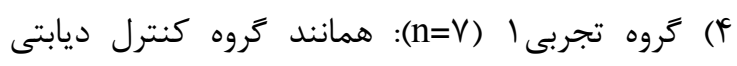
تيمار شده و علاوه بر آن از همان روز ه ه حاملتى تا يايان

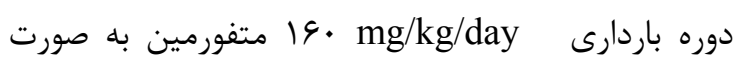

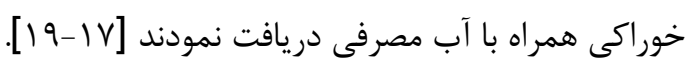

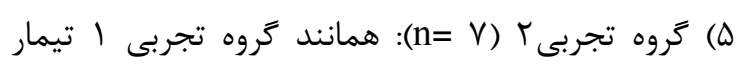

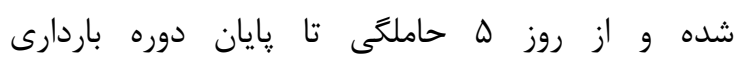
آ · mg/kg/day

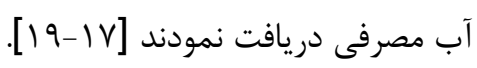

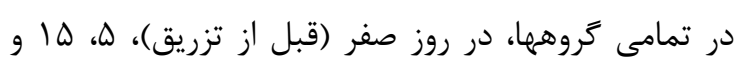

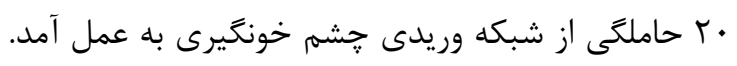

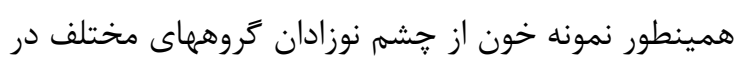

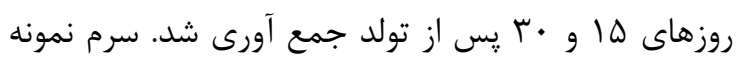

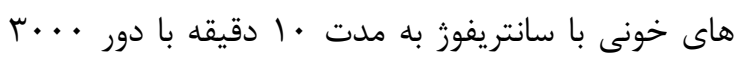
در دقيقه جدا شد و نمونه هاى سرم تا زمان اندازه كيرى ترى كليسريد، كلسترول تام، كلسترول LDL و و كلسترول دDL استفاده از كيتهاى روتين (شركت يارس آزمون) و دستخاه

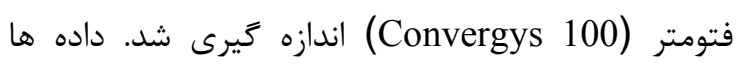
بصورت Mean t SEM بيان زرديد و با استفاده از آزمونهاى تى زوجى، آناليز واريانس و تست متعاقب توكى بـى بـى

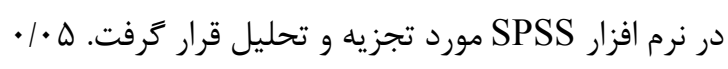

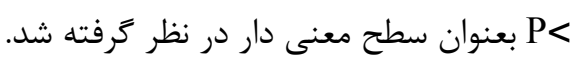

\section{يافته ها}

تائيد مدل هيير گليسمى: همانكونه كه در جـدول النشهـان

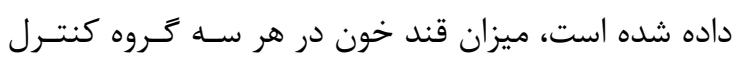

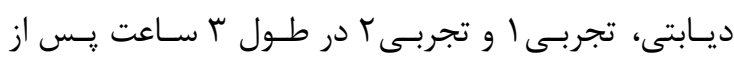

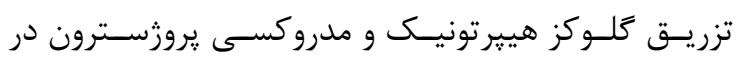
مقايسه با ساعت صفر افزايش معنى دارى يافته است.

\section{بررسى بيوشيميايى سرم رتههاى باردار :}

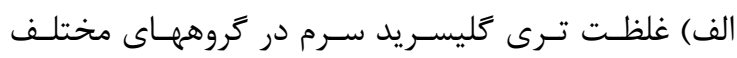
رتهــاى بــاردار در روزهــاى صــفر، ه، هاو • ب بــاردارى: 
جدول ا: ميزان قند خون (mg/dl) در ساعات قبل از تزريق كلوكز هييرتونيك و مدروكسى يروزسترون و در فواصل ال، كو ب ساعت بعد از

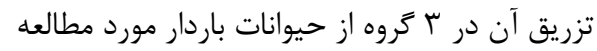

\begin{tabular}{|c|c|c|c|}
\hline \multicolumn{3}{|c|}{ غلظت قند خون (mg/dl) } & \\
\hline تجربى ז(متفورمين · · & تجربى (متفورمين • (1) & ديابتى(هيير گليسمى) & 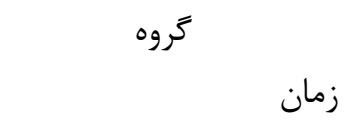 \\
\hline$|r| / F \pm \Delta / \cdot r \Lambda$ & $|r \cdot / \mathcal{f} \pm F /|$. & $11 r / 9 \pm 9 / 91$ & ساعت صفر (قبل از تزريق) \\
\hline $199 / V \pm V /\left.4\right|^{\text {***** }}$ & $199 \pm 9 / \Lambda \Delta^{* * * *}$ & $r \cdot \Delta / 1 \pm 1 \Delta / r \cdot{ }^{* * * *}$ & ساعت اول \\
\hline $\mid F T / V \pm r / 19^{\text {***** }}$ & $|r r / V \pm r / \varphi|^{*}$ & 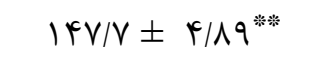 & ساعت دوم \\
\hline$\| r \cdot|\Delta \pm r /| r^{*}$ & $\mid r \Delta / r \pm r / \Lambda \varphi^{*}$ & $|r \varepsilon \pm r| q r^{*}$ & ساعت سوم \\
\hline
\end{tabular}

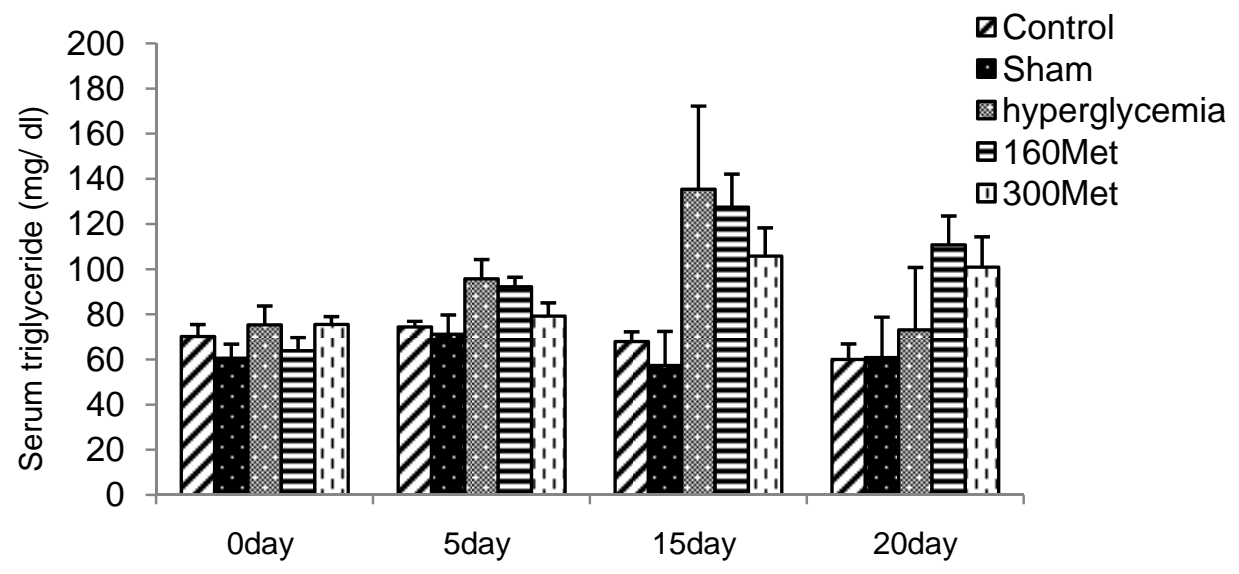

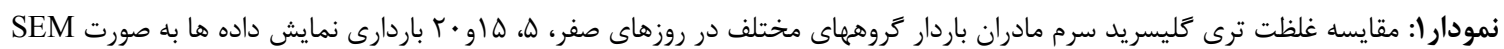

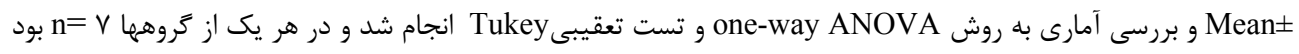



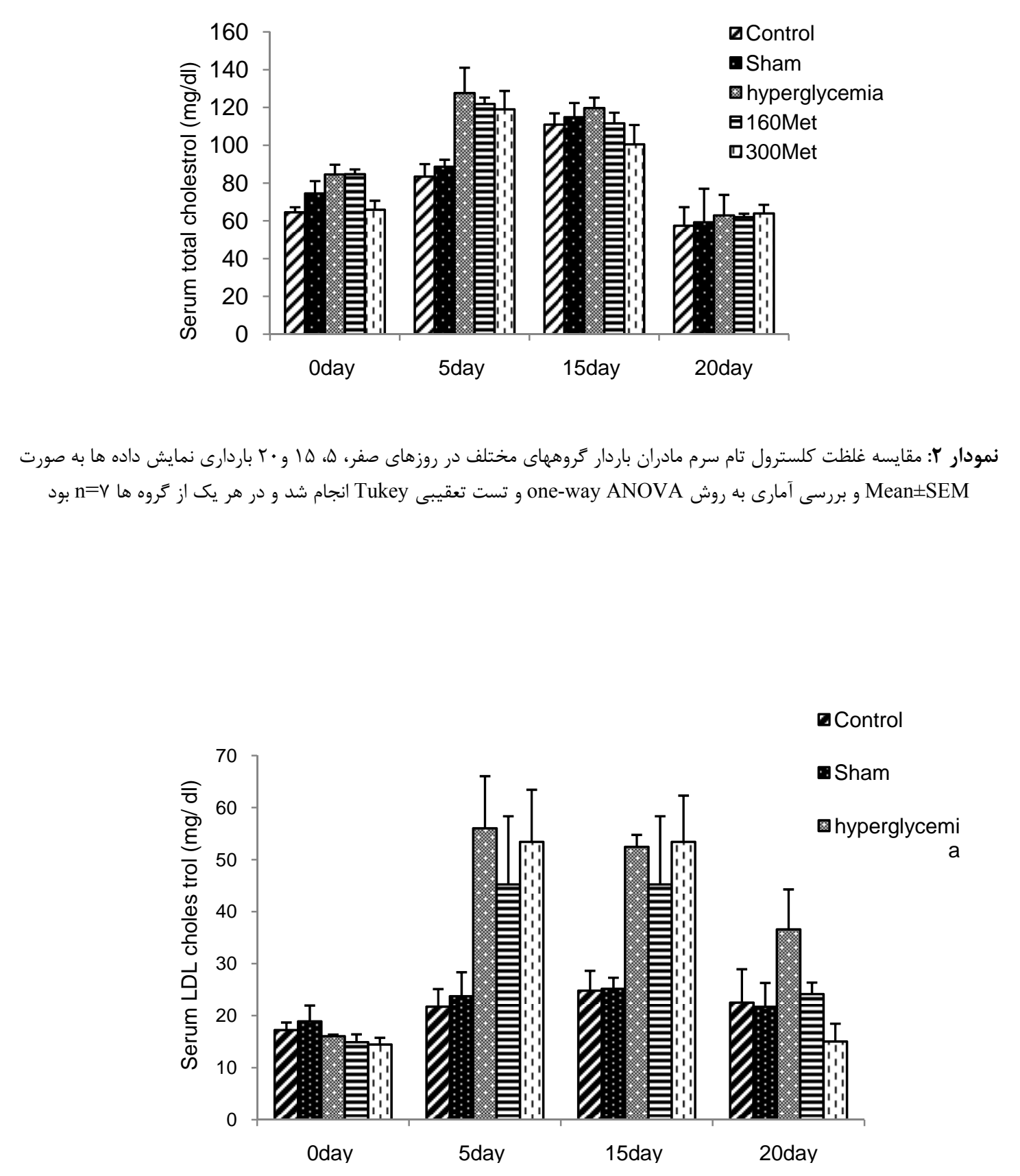

نمودار ץ: غلظت كلسترول LDL سرم مادران باردار گروههاى مختلف در روزهاى صفر، ه، ها و • • باردانمايش داده ها به صورت

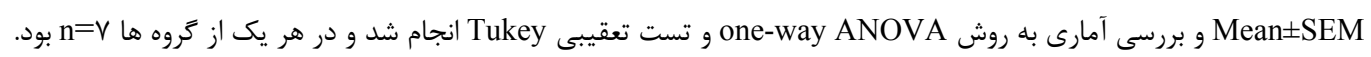




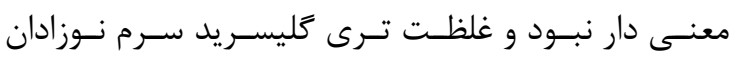

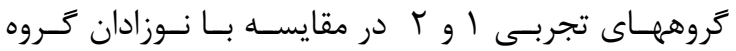

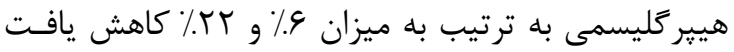

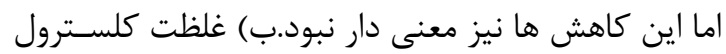

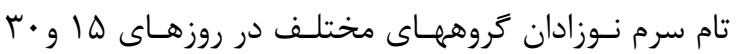
يس از تولد: همانكونه كه در نمودار 9 مشـاهده مسى شـود

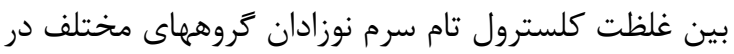

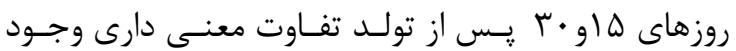
نداشت. ج) غلظت كلسترول LDL سرم نوزادان كروههاى مختلف در روزهاى ها و •r يس از تولد: همـانطور كـه در

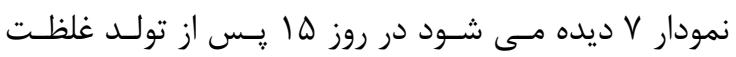

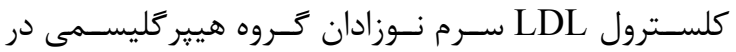
مقايسه با نوزادان گروه كنترل به ميزان آباء افزايش نشان

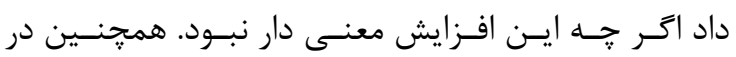
نوزادان كروههاى تجربى اوrا، غلظت كلسترول LDL سرم

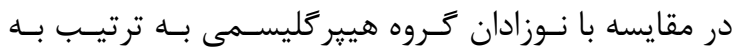

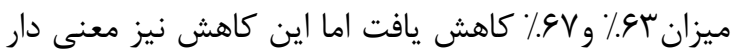

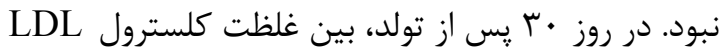
سرم نوزادان كروههاى مختلف، تفاوت معنى دارى مشاهده

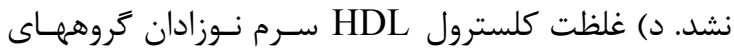

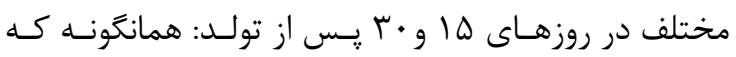

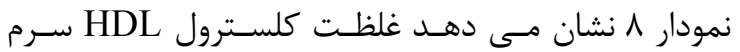

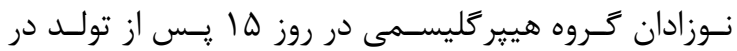

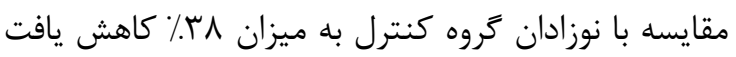

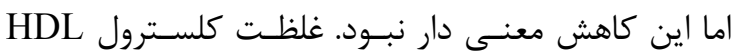

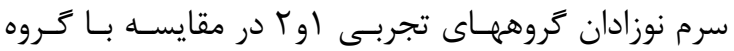

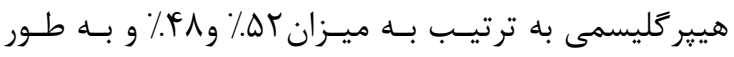

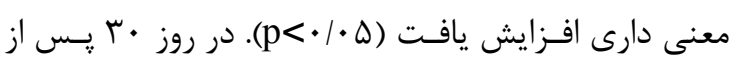

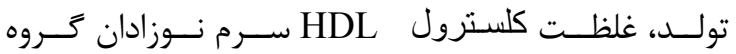

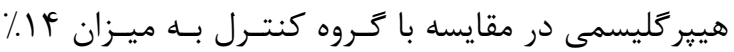

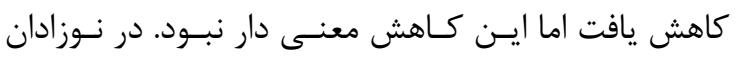
كروه تجربى ا، غلظت كلسترول HDL سرم در مقايسه بـا

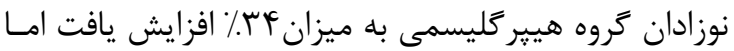

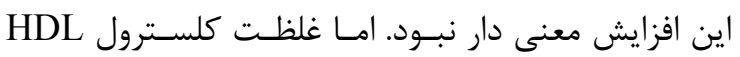

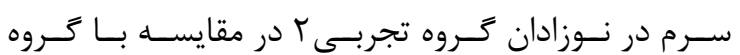

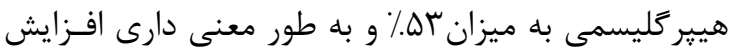

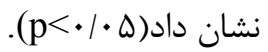

اما اين افزايش معنـى دار نبـود. غلظـت كلسـترول LDL سرم در گروه تجربى ا در مقايسه با كروه هيير كليسمى بـهـ طور جزئى كاهش يافت اما اين كاهش نيز معنى دار نبـود.

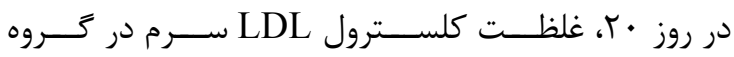

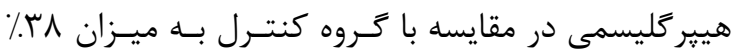

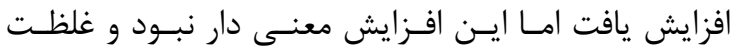

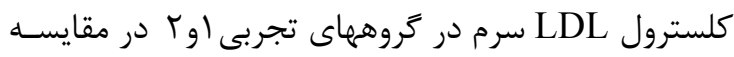

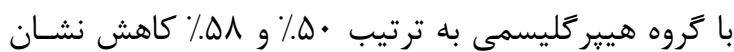
داد اما اين كاهش نيز معنى دار نبود.

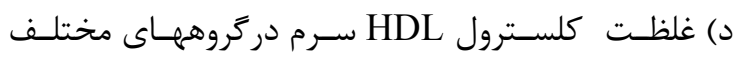

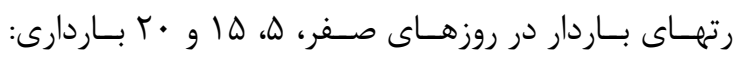

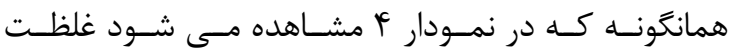

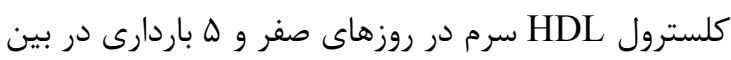

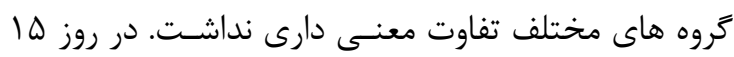

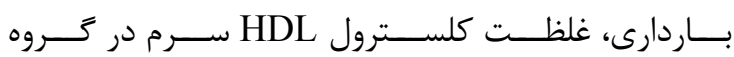

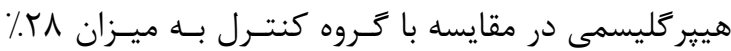

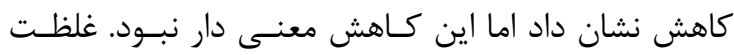

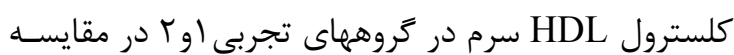

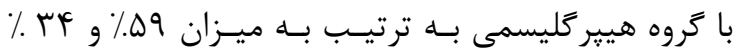

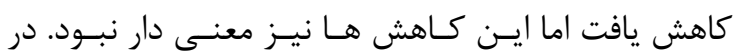

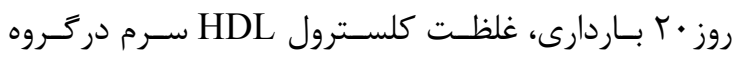

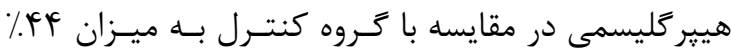
كاهش داشت و در گروههاى تجربى او r، غلظت كلسترول

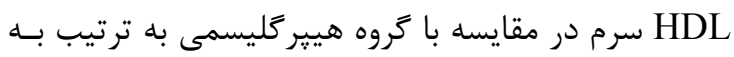

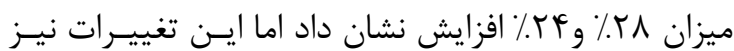

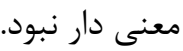

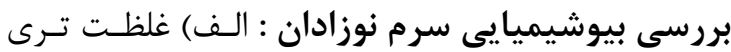

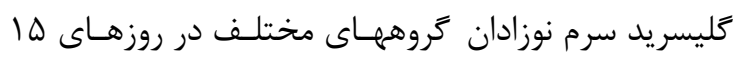

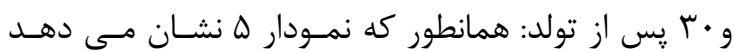

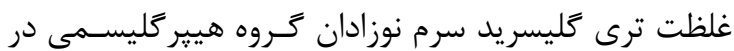

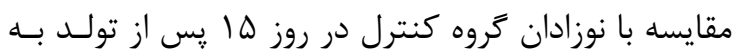

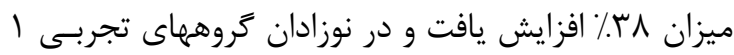
و r در مقايسه با نـوزادان كـروه هيير كليسـمى بـه ميـزان

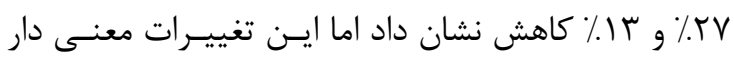

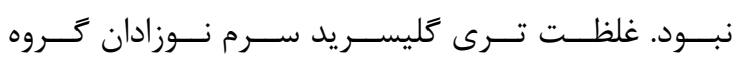

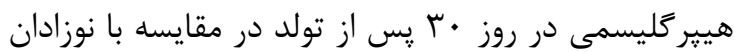

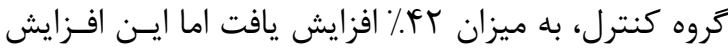




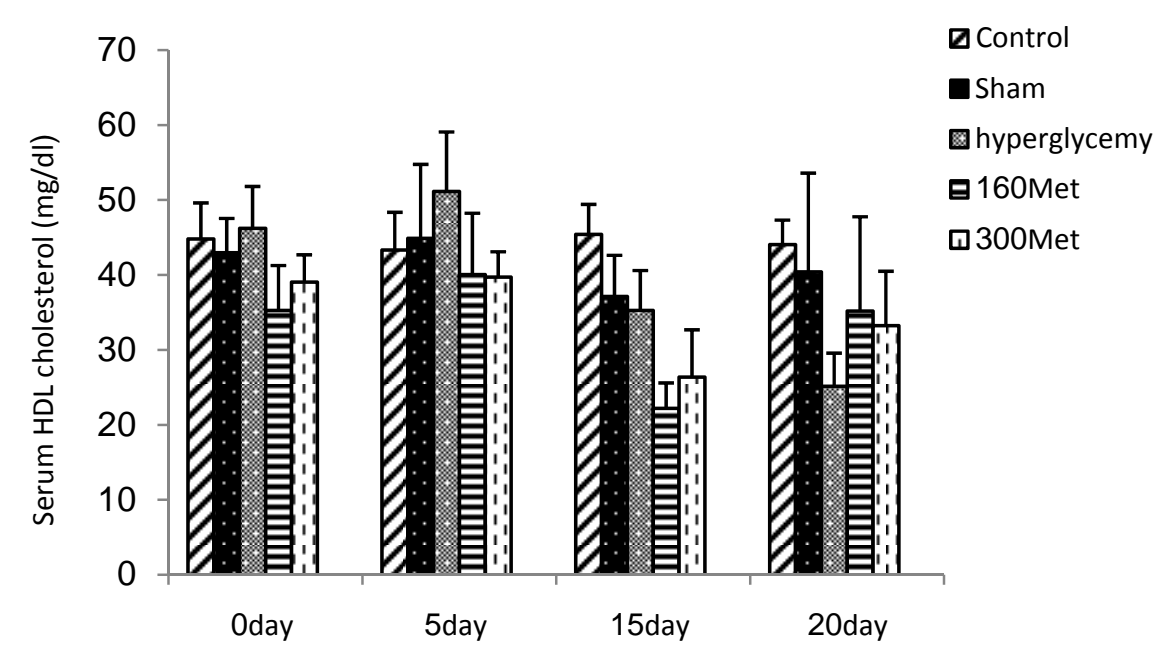

نمودار F: غلظت كلسترول HDL سرم مادران باردار كروههاى مختلف درروزهاى صفر، ه، ها و •r باردارى نمايش داده ها به صورت

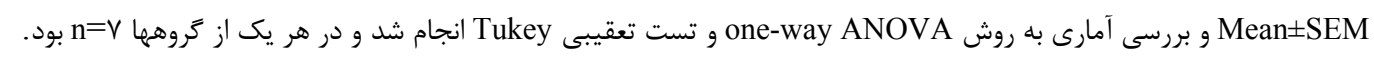

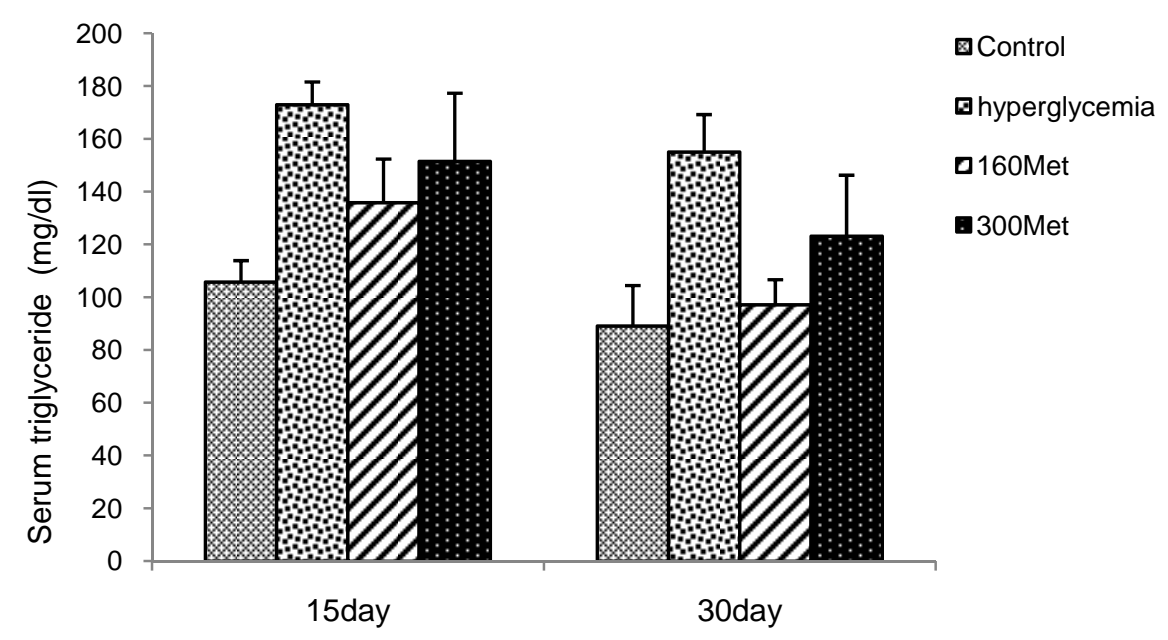

نمودار ه: غلظت ترى كَليسريد سرم نوزادان كروههاى مختلف در روزهاى هاو •r پس از تولد نمايش داده ها به صورت SEM

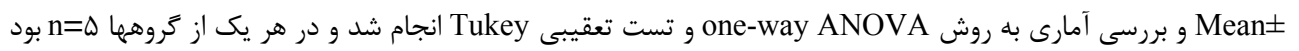




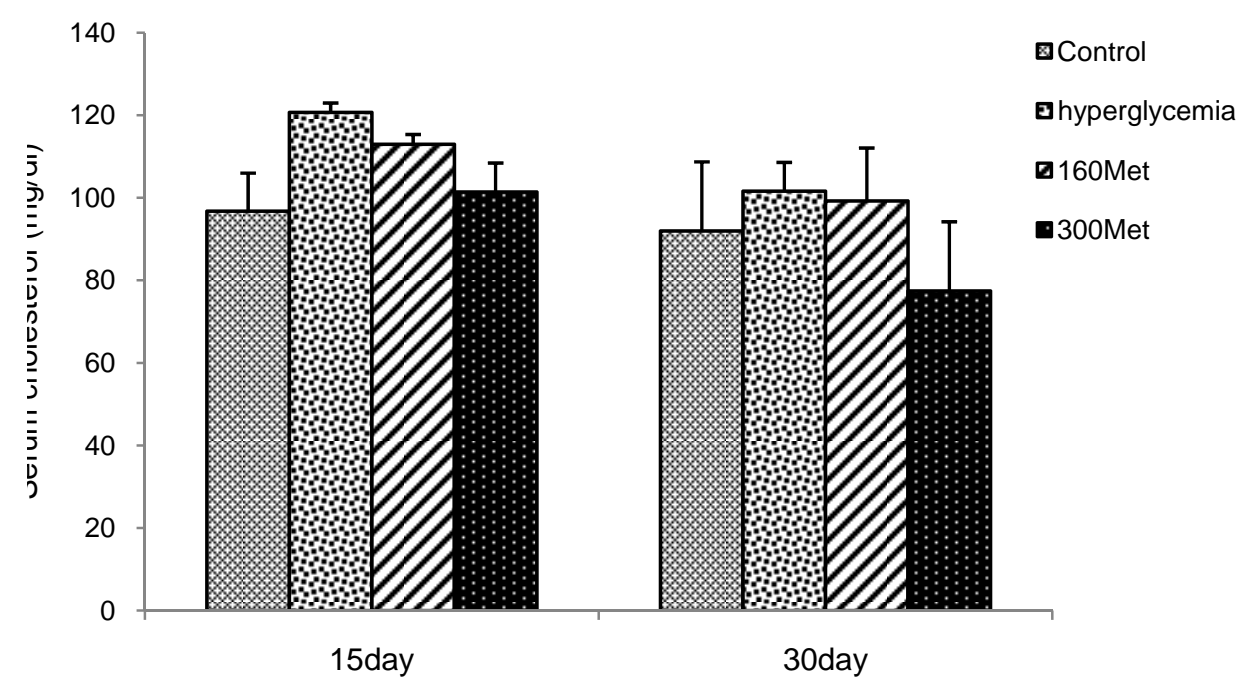

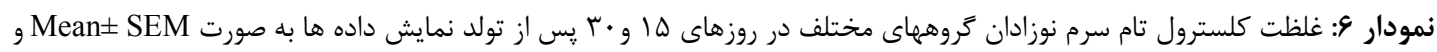

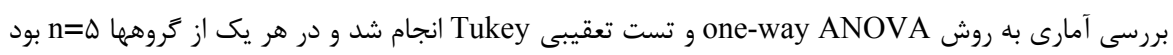

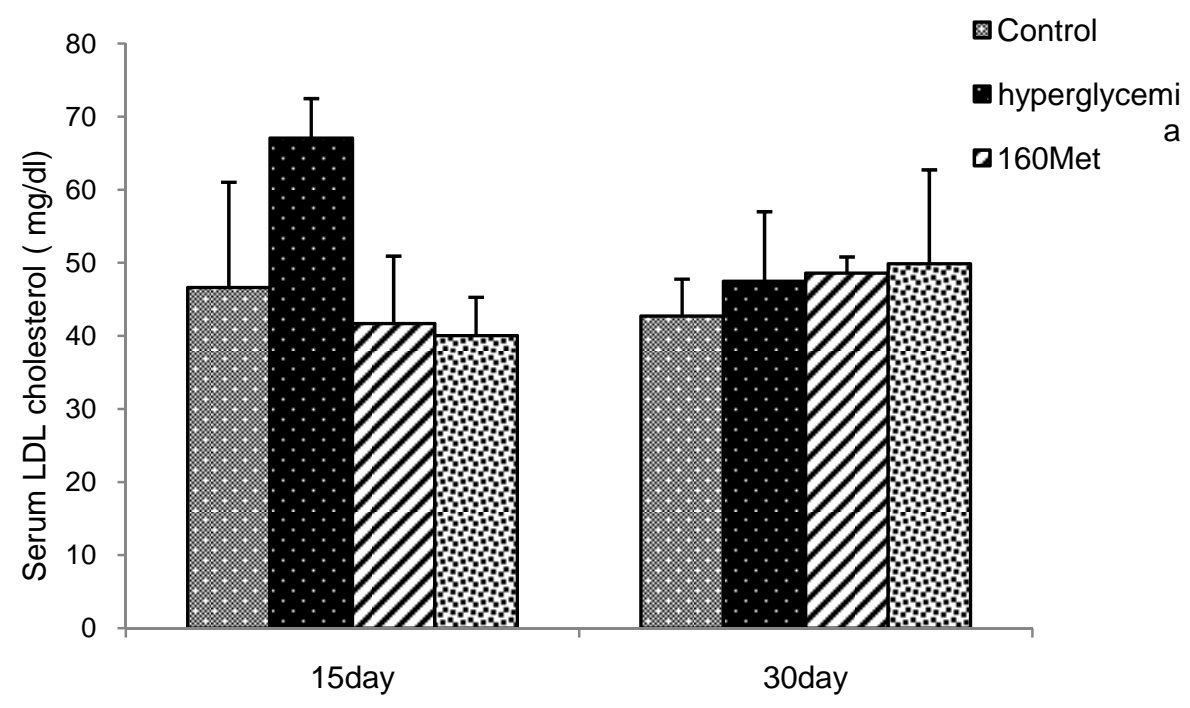

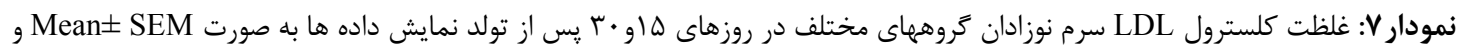

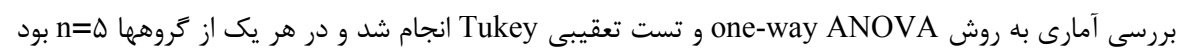




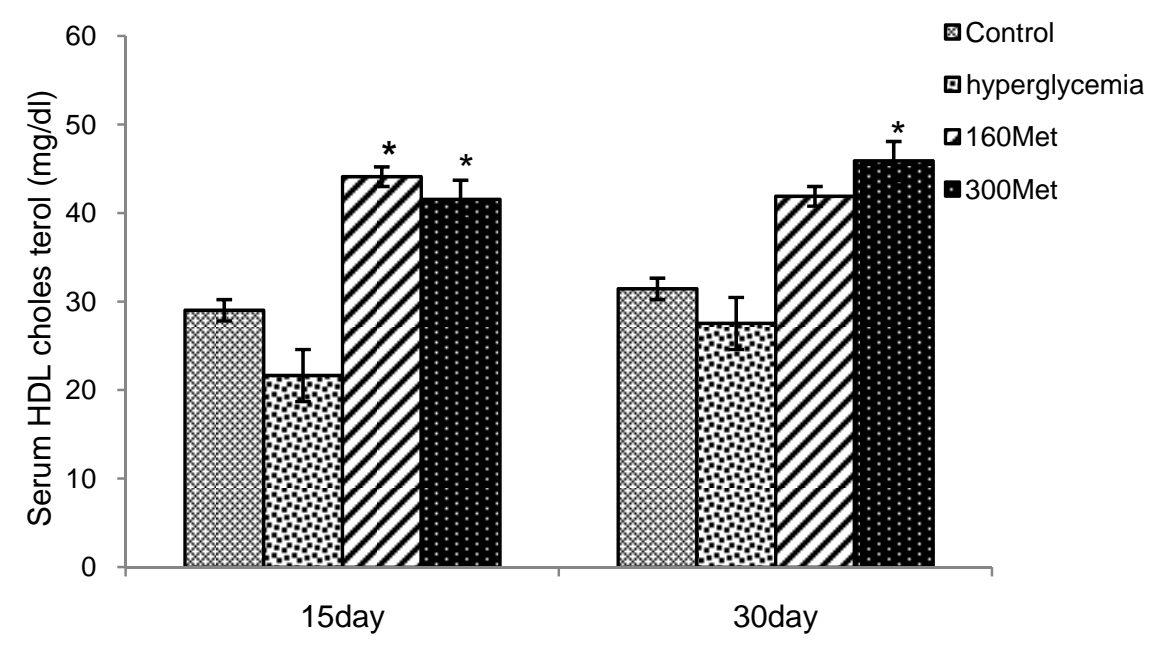

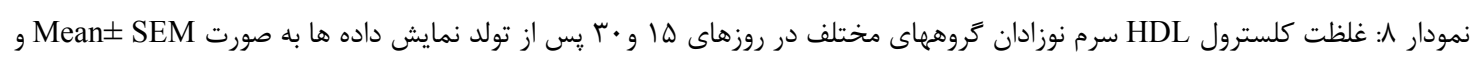

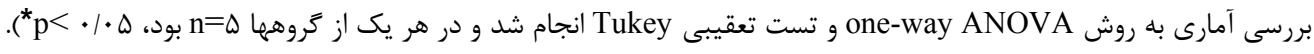

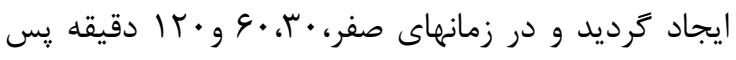

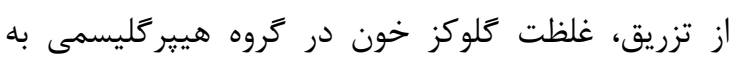
ترتيب

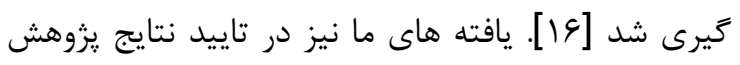

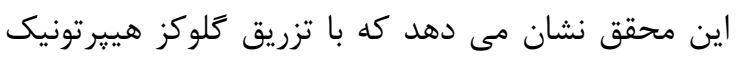

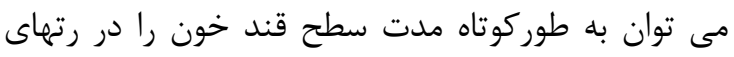
باردار افزايش داد. در يزوهش ديخرى كه توسط حسين

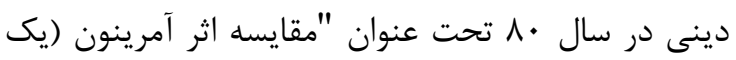

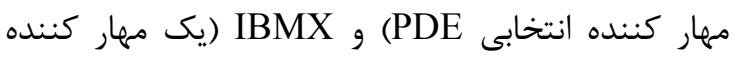

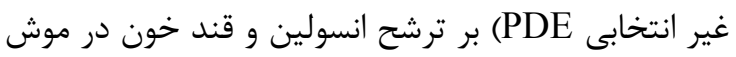

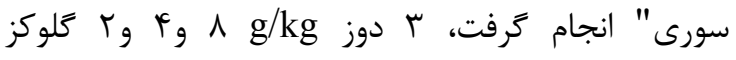

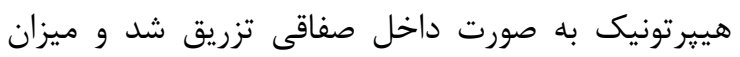

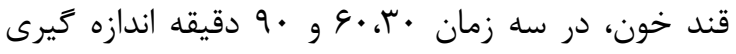

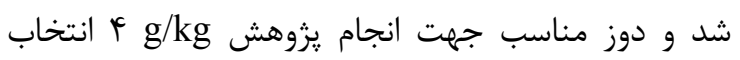

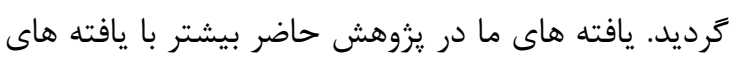

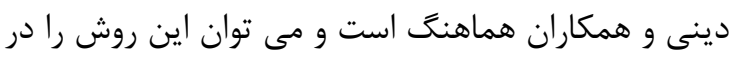

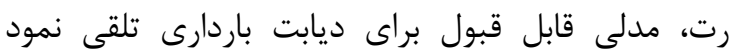

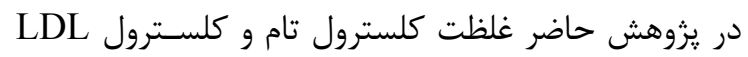

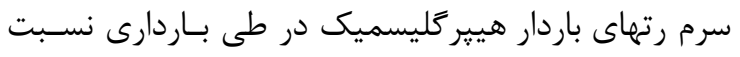

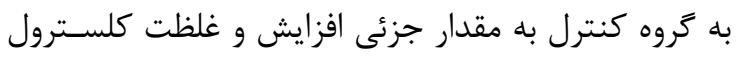
كاهش يافت. بنظر مى رسد اين تغييرات جزئى بــهـ

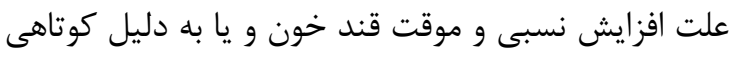

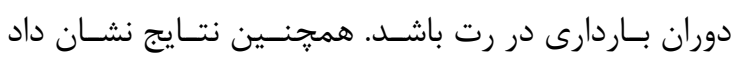

نتايج مطالعه حاضر حاكى از اين است كه با تزريق كلوكز

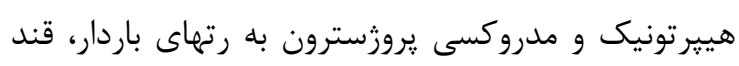

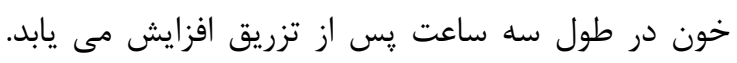

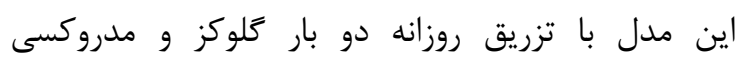

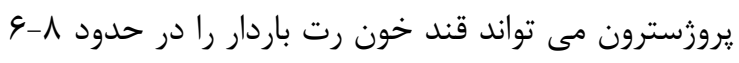

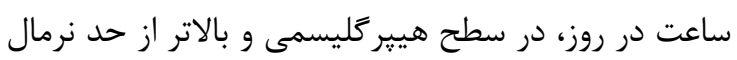
نحة دارد كه حالتى شبيه ديابت باردارى است. براى تشخيص قطعى ديابت باردارى علاوه بر توجه به قند دارد آند

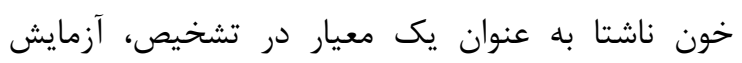

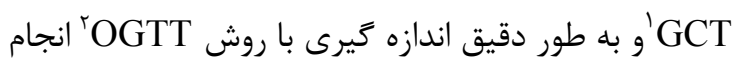

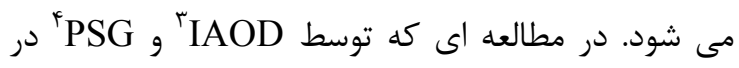

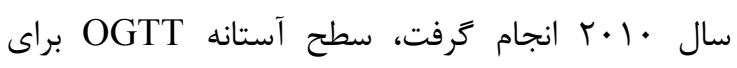

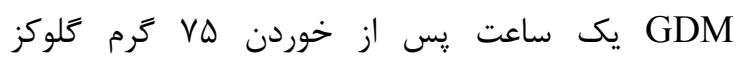

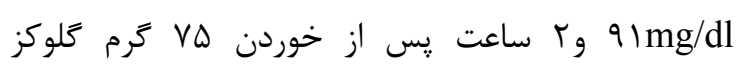
إ.

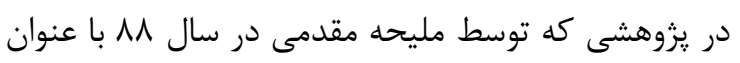

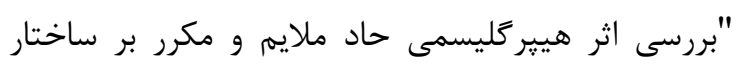

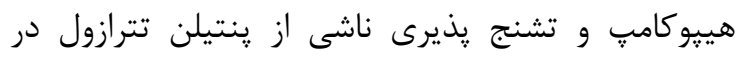

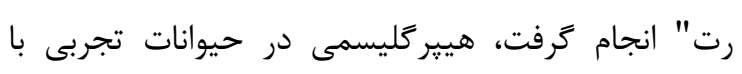

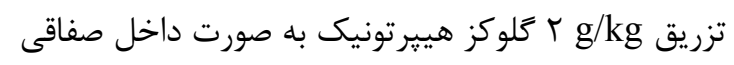

1. Glucose Challenge Test

2. Oral glucose tolerance test

3. International Association of Diabetes 4. Pregnancy Study Groups 
تغييرات فاكتورهاى بيوشيميايى خون از جمله كلسترول و اختلالات ناشى از آن در كوتاه مدت مدل مناسبى اسـت و و

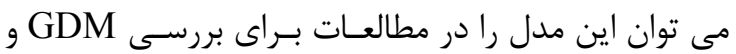

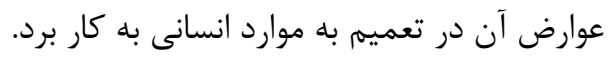

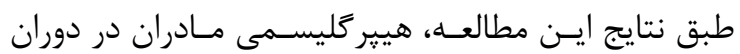

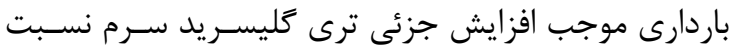

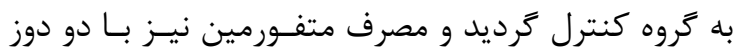

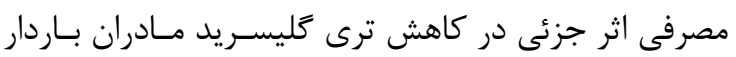

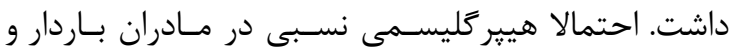

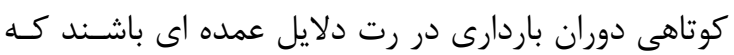

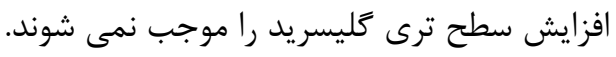

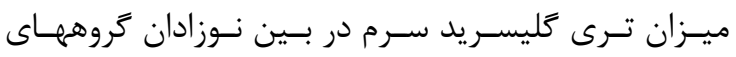

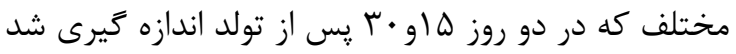

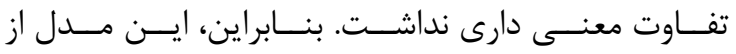

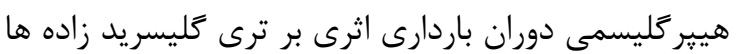

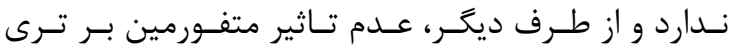

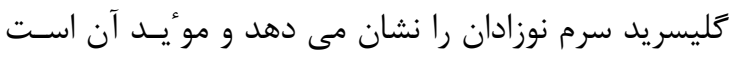

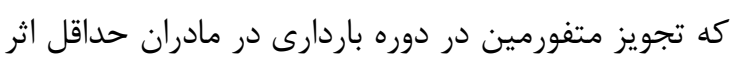
بر سطح ترى كليسريد نوزادان آنها در فاصله يـك ماهـهـ از داز

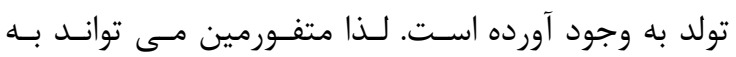

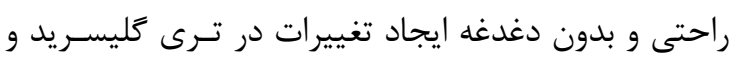

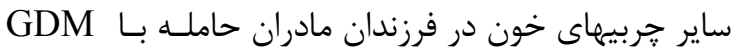
مصرف شود. اگر جه تغييرات در سطوح قنـد، كلسـترول و ورناف

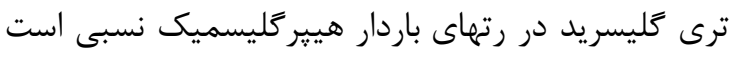

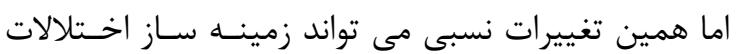
متابوليكى وبرخى از عوارض كـردد كـه در دوران بـاردارى ندي

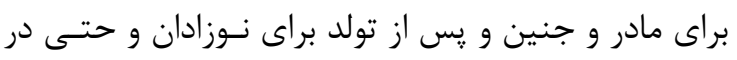

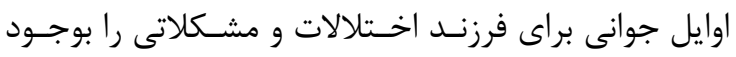

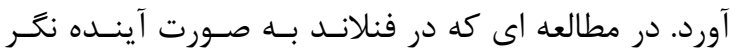

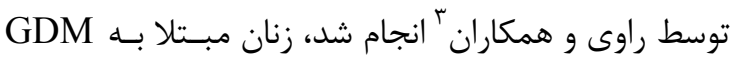

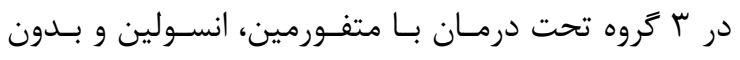
درمان قرار كرفتند، يافته ها تفاوتى بين گرووه متفورمين و ودين

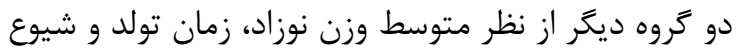

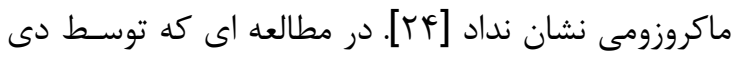

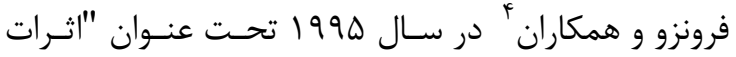

3. Ravi

4 .DeFronzo Ralf et al
غلظت كلسترول تـام و كلسـترول LDL سـرم در رتهـاى

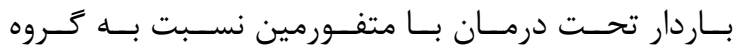
هيير كليسمى به طور جزئى و غيـر معنسى دارى كـاهش و غلظت HDL در روز • ب باردارى افزايش يافت. در مطالعه

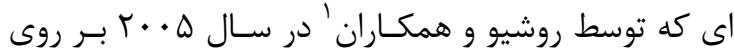
هץ زن باردار مبتلا به سندرم تخمدان يلى كيستيك كه و

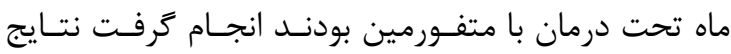

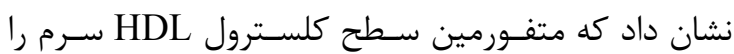
افزايش و سطح كلسترول تام و ترى كليسريد سـرم را نيـز

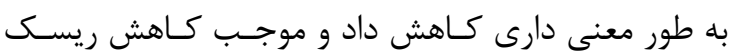

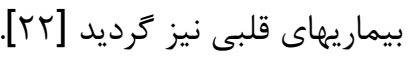
در مجموع با توجه به اينكه در اين مطالعه تغييرات غلظت كلسترول در رتهاى باردار هيير كليسميك جزئى است، بـهـ نظر مى رسد كه در ايـن شـرايط افـزايش جزئسى و كوتـاه

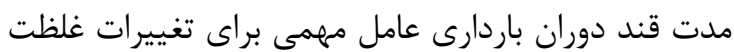

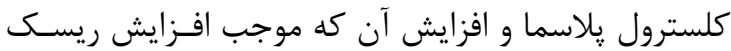
بيماريهاى قلبى عروقى گردد نمى باشد. تجويز متفـورمين

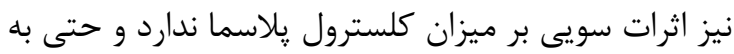
طور نسبى آنرا كاهش مى دهي دهد.

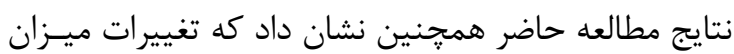
كلسترول در نوزادان مـادران هيير كَليسـميك در روزهـاي

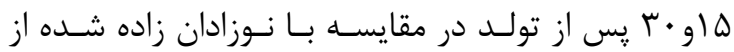

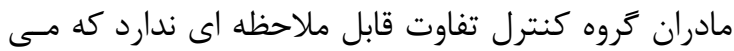

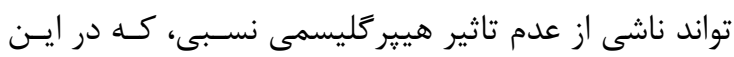

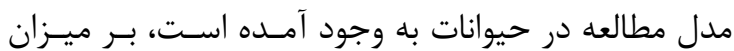
كلسترول باشد. در مطالعه اي كه توسط كلواك بَ وهمكاران

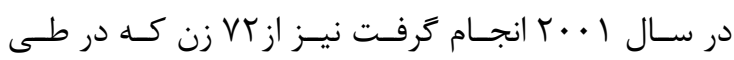

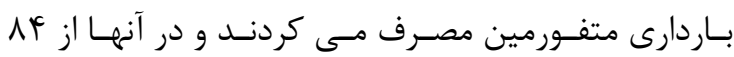
جنين، بَع تولد زنده طبيعى و بدون نقص مادرزادى متولد

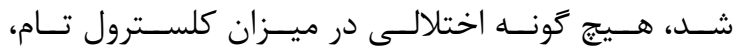

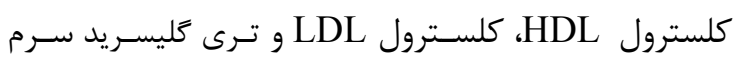
مادران و نوزادان آنها وجود نداشت [بr]. يافته هاى مـا در يزوهش حاضر نيز مويد نتايج اين محققـين اسـت و بنظـر

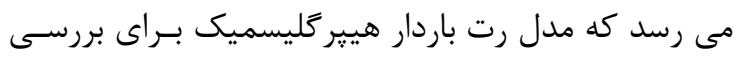

\section{Rautio}

2. Glueck 


\section{نتيجه كيرى}

با توجه به اينكه هيير كليسمى ايجاد شده در اين مطالعه

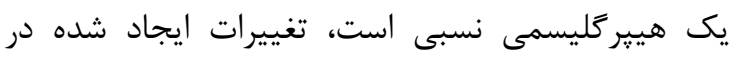

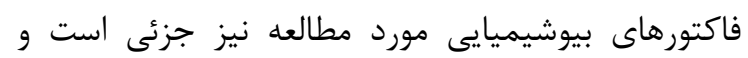

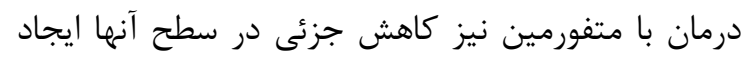

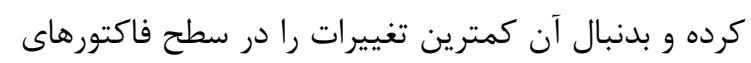

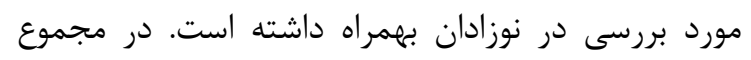

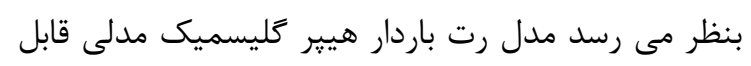

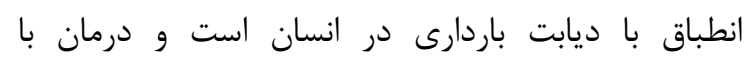

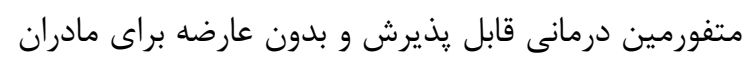

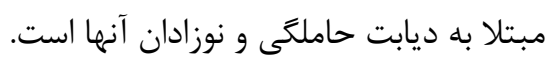

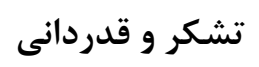

نويسندًان مقاله مراتب تشكر و قدردانى خود را از معاونت

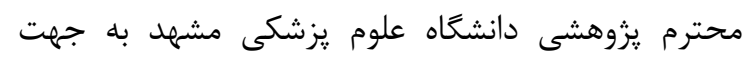
حمايت مالى يزوهش حاضر اعلام مى دارند.

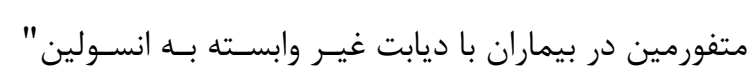

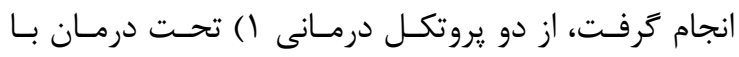

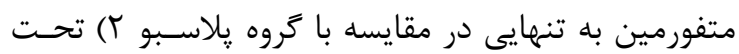

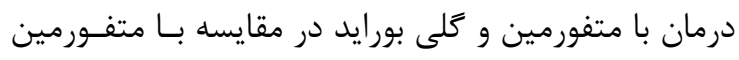
به تنهايى و كلى بورايد به تنهايى استفاده شد. نتايج نشان

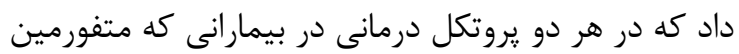

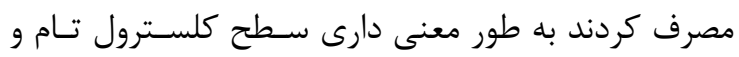

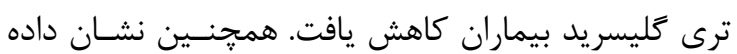

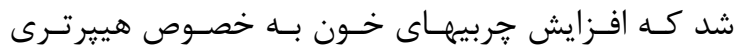

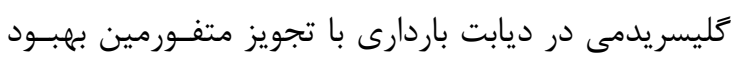

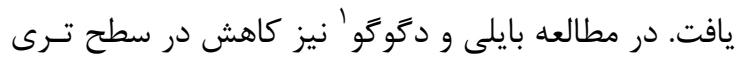

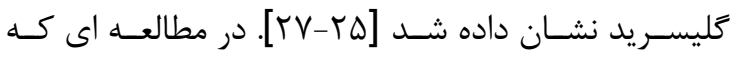

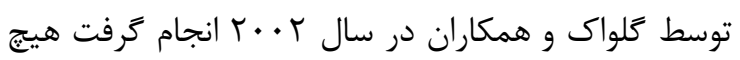

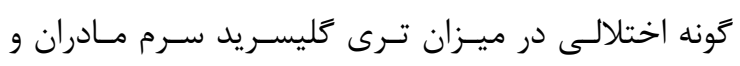

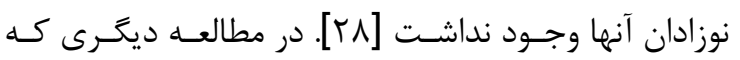
توسط همـين محققـين بـر روى زنـان مبـتلا بـهـ ســندرم

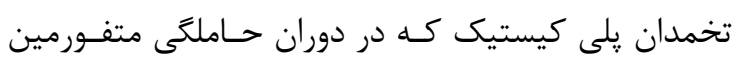

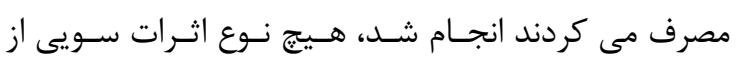

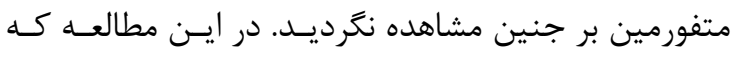

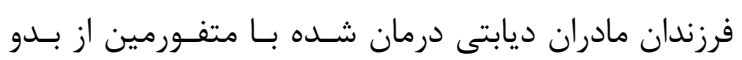

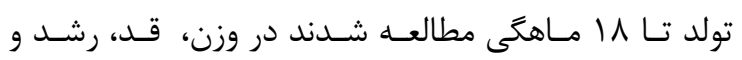

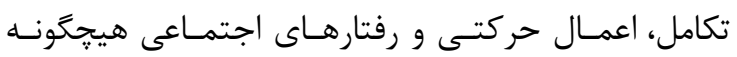

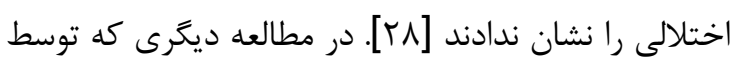

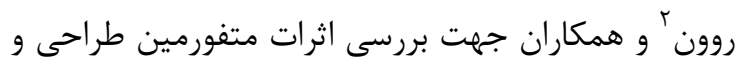

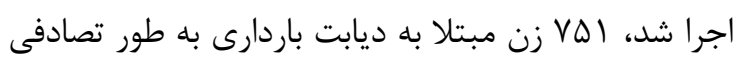

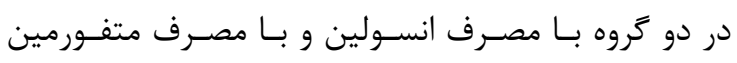

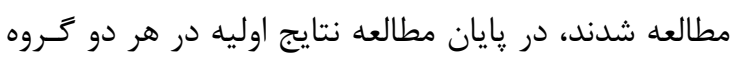

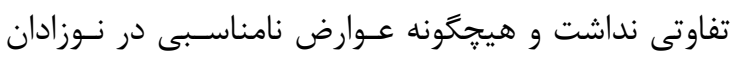

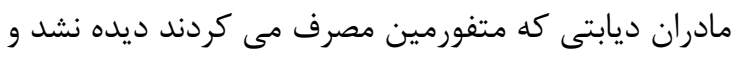

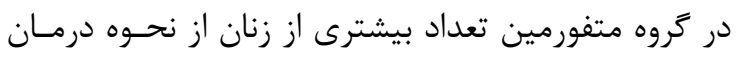

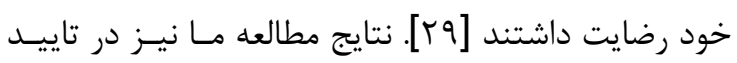

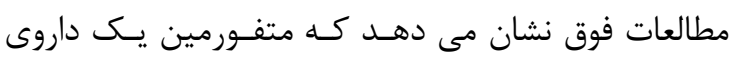

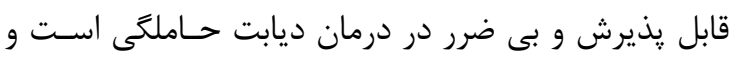

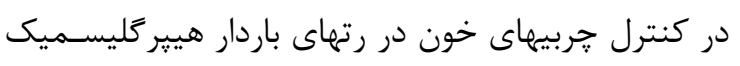
موثر است. - مون

1. Bailey \& Dagogo.

2. Rowan 


\section{References}

1. Harrison TR, Principles of Internal Medicine, Tehran, 1991.

2. Cheung NW, The management of gestational diabetes, Vasc Health Risk Manag 2009; 5(1):153-64.

3. Khosh-Niat Niko M, Abaszadeh Ahranjani SH, Larijani B, Prevalence of Gestational Diabetese in Iran, Iran J Diab Lipid 2008; 8(1):1-10.

4. Zhao J, Weiler HA, Long-term effects of gestational diabetes on offspring health are more pronounced in skeletal growth than body composition and glucose tolerance, B J Nutr 2010; 104(11):1641-9.

5. Moore TR, Fetal exposure to gestational diabetese contributes to subsequent adult metabolic syndrome, Am J Obstet Gynecol 2010; 202(6):643-9.

6. Hedderson MM, Ferrara A, High blood pressure before and during early pregnancy is associated with an increased risk of gestational diabetes mellitus, Diabetes Care 2008;31(12):2362-7.

7. Langer O, Mazze R, The relationship between large-for-gestational age infant and glycemic control in women with gestational diabetes, Am J Obstet Gynecol 1988; 159(6):1478-83.

8. Hod M, Merlob P, Friedman, S, "et al", Gestational diabetes mellitus: a survey of perinatal complications in the 1980s, Diabetes 1991; 40(2):74-8.

9. Ecker JL, Greenberg, JA, Norwitz ER,"et al“, Birth Weight as a predictor of brachial plexus injury, Obstet Gynecol 1997;89:643-7.

10. Jang H, Cho N, Min Y, Han I, Jung K, Metzger B, Increased macrosomia and perinatal morbidity independent of maternal obesity and advanced age in Korean women with GDM, Diabetes Care, 1997;20(10):1582-8.

11. Kjos S, Buchanan T, Greenspoon J, Montoro M, Bernstein G, Mestman J, Gestational diabetes mellitus: the prevalence of glucose intolerance and diabetes mellitus in the first two months post partum, Am J Obstet Gynecol 1990;163:93-8.

12. Hughes R, Rowan J, Pregnancy in women with Type 2 diabetes: who takes metformin and what is the outcome ? Diabet Med 2006; 23(3):318-22.

13. Kapoor N, Sankaran S, Hyer S, Shehata H, Diabetes in pregnancy: a review of current evidence, Curr Opin Obstet Gynecol 2007; 19(6):586-90.

14. Leis D, Bottermann P, Ermler R, Henderkott U, Glück H, The influence of high doses of oral medroxyprogesterone acetate on glucose tolerance, serum insulin levels and adrenal response to ACTH A study of 17 patients under treatment for endometrial cancer, Obstet Gynecol 1980; 230(1):9-13.

15. Spellacy W, McLeod A, Buhi W, Birk S, McCreary S, Medroxyprogesterone acetate and carbohydrate metabolism: measurement of glucose, insulin, and growth hormone during 6 months' time, Fertil Steril 1970;21(6):457.

16. Moghadami M, Study of Effect of repeated mild acute hyperglycemia of structure of hippocompus and PTZ induced seizures inrat, Ferdowsi university of mashhad faculty of Sciences Department of Biology, September 2009[persian].

17. Verma S, Effect of metformin treatment on isolated cardiac function and blood pressure in diabetic and hypertensive rats, University of British columbia 1993.

18. Verma S, Bhanot S, McNeill JH, Antihypertensive effects of metformin in fructose-fed hyperinsulinemic, hypertensive rats, Pharmacol Exp Ther 1994; 271(3):1334-1337.

19. Kim YW, Kim JY, Park YH, Park SY, Won KC, Choi KH, Huh JY, Moon KH Metformin restores leptin sensitivity in high-fat-fed obese rats with leptin resistance, Diabetes 2006 Mar;55(3) 716-724.

20. The Internattional Association of Diabetese and Pregnancy Study Groups recommendations on the diagnosis and classification of hyperglycemia in pregnancy, Diabetese care 2010; 33:676-82.

21. Dinni H, Comparing The Effects of Amrinon, Aselective PDE3 inhibitor and IBMX, A non-Selective PDE inhibitor on Insulin Secretion and plasma glucose concentration in mouse, Mashhad university of Medical scinces, school of pharmacy 2001.

22. Rautio K,Tapanainen J, Ruokonen A, Morin-Papunen L, Effects of metformin and ethinyl estradiolcyproterone acetate on lipid levels in obese and non-obese women with polycystic ovary syndrome, Eur $\mathrm{J}$ Endocrinol 2005;152(2):269-75.

23. Glueck C, Phillips H, Cameron D, Sieve-Smith L, Wang P, Continuing metformin throughout pregnancy in women with polycystic ovary syndrome appears to safely reduce first-trimester spontaneous abortion: a pilot study, Fertil Steril. 2001;75(1):46-52. 
24. Ravi K, Rajasekaran S, Subramanian S, Antihyperlipidemic effect of Eugenia jambolana seed kernel on streptozotocin-induced diabetes in rats, Food Chem Toxicol 2005; 43(9):1433-9.

25. DeFronzo RA, Goodman AM, Efficacy of metformin in patients with non-insulin-dependent diabetes mellitus, N Engl J Med 1995;333(9):541-9.

26. Bailey C, Turner RC, Drug therapy: metformin, N Engl J Med 1996;334(9):574-9.

27. Dagogo-Jack S, Santiago JV, Pathophysiology of type 2 diabetes and modes of action of therapeutic interventions, Arch Intern Med 1997;157(16):1802.

28. Glueck C, Wang P, Kobayashi S, Phillips H, Sieve-Smith L, Metformin therapy throughout pregnancy reduces the development of gestational diabetes in women with polycystic ovary syndrome, Fertil Steril 2002;77(3):520-5.

29. Rowan JA, Hague WM, Gao W, Battin MR, Moore MP, Metformin versus insulin for the treatment of gestational diabetes, N Engl J Med 2008;358(19):2003-15. 


\title{
The effect of metformin on serum lipid levels in hyperglycemic pregnant rats and their newborns
}

\author{
Rajaei $Z^{1}$, Hadjzadeh $M R^{2 *}$, Nazari $A^{3}$, Shams $M^{4}$ \\ ${ }^{1}$ Assistant Professor of Physiology, Mashhad University of Medical Sciences, Mashhad, Iran. \\ ${ }^{2}$ Professor of Physiology, Mashhad University of Medical Sciences, Mashhad, Iran. \\ ${ }^{3}$ M.Sc of Physiology, Mashhad University of Medical Sciences, Mashhad, Iran. \\ ${ }^{4}$ Student of Medicine, Hamadan University of Medical Sciences, Hamadan, Iran.
}

\begin{abstract}
*Corresponding Author:
Department of Physiology, School of Medicine, Mashhad University of Medical Sciences, Mashhad, Iran.

E-mail: hajzadehmr@mums.ac.ir
\end{abstract}

Submitted: 2012 Feb 7

Revised: 2012 Apr 3

Accepted: 2012 Apr 5

\begin{abstract}
Background \& Objectives: Gestational diabetes is an state of glucose intolerance that is diagnosed during pregnancy. Metformin is a biguanide oral hypoglycemic agent and is used in treatment of type 2 diabetes mellitus, but its use in treatment of gestational diabetes has been controversial. The purpose of the present study was to investigate the effects of metformin on serum lipid profile in hyperglycemic pregnant rats and their progenies.

Materials \& Methods: Female Wistar rats were randomly divided into 5 groups: intact control, sham, hyperglycemic and 2 experimental groups treated with metformin at doses of 160 and 300 $\mathrm{mg} / \mathrm{kg}$. The hyperglycemia was induced by the intraperitoneal injection of hypertonic glucose $(4 \mathrm{~g} / \mathrm{kg})$ and medroxyprogesterone $(3 \mathrm{mg} / \mathrm{kg})$ twice daily since the 5th day of pregnancy through the end of the gestational period. Furthermore, experimental groups received 160 and $300 \mathrm{mg} / \mathrm{kg}$ metformin in drinking water since 5th day of gestation through the end of the pregnancy. The maternal blood samples were taken on days $0,5,15$ and 20 of pregnancy, while neonatal samples were collected on postnatal days of 15 and 30. Biochemical factors (triglyceride, total cholesterol, LDL-cholesterol and HDL-cholesterol) were measured spectrophotometrically by routine laboratory techniques.
\end{abstract}

Results: Following injection of hypertonic glucose and medroxyprogesterone, serum glucose levels were significantly increased in hyperglycemic pregnant rats compared to control. Serum triglyceride and cholesterol levels in hyperglycemic pregnant rats and their newborns were partially increased in comparison to control group. Treatment of hyperglycemic pregnant rats with metformin at dosages of 160 and $300 \mathrm{mg} / \mathrm{kg}$ decreased the lipid levels in the mothers and their newborns compared to hyperglycemic group, although the changes were not significant.

Conclusion: Our findings suggest that the hyperglycemic pregnant rat model is a reliable model for gestational diabetes in human. Metformin is a safe and effective treatment for rat dams during gestational diabetes and their progenies. Therefore, it may be suggested that metformin can be used in treatment of gestational diabetes in pregnant women.

Keywords: Gestational diabetes, Metformin, Hyperglycemia, Lipid, Newborns, Rat. 